\title{
Peran Guru Akidah Akhlak dalam Menanamkan Karakter Siswa
}

\author{
Muhamad Suyudi \\ Program Pascasarjana Institut Agama Islam Sunan Giri (INSURI) Ponorogo \\ muhamadsuyudi@insuriponorogo.ac.id
}

\author{
Nasrul Wathon \\ Madrasah Aliyah Al-Falah Karangrejo Pacitan
}

Naskah diterima: 20 Oktober 2020 | Disetujui: 25 November 2020 | Diterbitkan: 5 Desember 2020

\begin{abstract}
This study's objectives were to describe the role of the Akidah Akhlak teacher in instilling the character of MA students. This research is field research with qualitative methods employing particular procedures. The results showed that Akidah Akhlak teachers' role in instilling MA AlFalah students' character values Karangrejo Pacitan had a significant influence on students. The strategies adopted by the teacher include advising students to come on time, to obey madrasa regulations and teacher orders, to maintain the madrasa's cleanliness by not littering, not carrying cellphones and valuables, not making the class messy, and giving sanctions for students who violate it. Several supporting and inhibiting factors were found at MA Al-Falah Karangrejo Pacitan, yet the aim in instilling student character values is well achieved.
\end{abstract}

Keywords: education, instilling character, student, teacher

\begin{abstract}
Abstrak
Tujuan penelitian ini adalah mendeskripsikan peran guru Akidah Akhlak dalam menanamkan karakter siswa MA. Penelitian ini merupakan penelitian lapangan dengan metode kualitatif dengan prosedur tertentu. Hasil penelitian menunjukkan bahwa peran guru Akidah Akhlak dalam menanamkan nilai-nilai karakter siswa MA Al-Falah Karangrejo Pacitan mempunyai pengaruh yang signifikan terhadap siswa. Strategi yang ditempuh guru antara lain menasihati siswa untuk datang tepat waktu, mematuhi peraturan madrasah dan perintah guru, menjaga kebersihan madrasah dengan tidak membuang sampah sembarangan, tidak membawa handphone dan barang berharga, tidak membuat berantakan kelas, dan memberikan sanksi bagi siswa yang melanggar. Beberapa faktor pendukung dan penghambat ditemukan di MA Al-Falah Karangrejo Pacitan, namun tujuan penanaman nilai karakter siswa tercapai dengan baik.
\end{abstract}

Kata Kunci: guru, pendidikan, penanaman karakter, siswa 


\section{Pendahuluan}

Problem kemerosotan moral akhir-akhir ini menjangkiti sebagian generasi muda. Gejala kemerosotan moral antara lain diindikasikan dengan merebaknya kasus penyalahgunaan narkoba, pergaulan bebas, kriminalitas, kekerasan, dan aneka perilaku kurang terpuji lainnya. Di lain pihak, tidak sedikit dari generasi muda yang gagal menampilkan akhlak terpuji (akhlāq maḥmūdah) sesuai harapan orang tua (Budiwan et al, 2020). Kesopanan, ramah, tenggang rasa, rendah hati, suka menolong, solidaritas sosial, dan sebagainya yang merupakan jati diri bangsa berabad-abad seolaholah kurang begitu melekat secara kuat dalam diri mereka (Lubis, 2009). Hal tersebut dapat dipengaruhi melalui perkembangan ilmu pengetahuan dan teknologi yang berkembang besarbesaran saat ini.

Kondisi yang tertulis di atas kurang mencerminkan sebagaimana label sekolah berbasis Islami yang seharusnya menjadi contoh bagi masyarakat maupun sekolah-sekolah yang lain. Upaya dari guru melihat kondisi tersebut memberikan teguran atau hukuman kepada siswa yang bermasalah, sebagian siswa ada yang mengindahkan dari teguran tersebut tetapi masih ada siswa yang tidak mengindahkan teguran tersebut dan siswa pun hanyak takut kepada beberapa guru saja. Hal seperti itu yang perlu diperhatikan oleh para guru dalam membentuk karakter siswa kembali melelui pembiasaan. Krisis yang melanda pelajar (juga elit politik) mengindikasikan bahwa pendidikan agama dan moral yang didapat di bangku sekolah (kuliah) tidak berdampak terhadap perubahan perilaku manusia Indonesia. Bahkan yang terlihat adalah begitu banyak manusia Indonesia yang tidak koheren antara ucapan dan tindakannya. Kondisi demikian, diduga berawal dari apa yang dihasilkan oleh dunia pendidikan (Zubaidi, 2011).

Salah satu media penumbuhan karakter adalah adanya madrasah/sekolah. Pada kenyataanya, Madrasah Aliyah (MA) Al-Falah Karangrejo Pacitan ikut andil dalam pembentukan tersebut melalui proses belajar mengajar. Hasil wawancara mengungkap bahwa kondisi di MA Al-Falah masih didapati siswa yang kerap menunjukkan perilaku kurang terpuji. Sebagian siswa MA AlFalah Karangrejo ada yang kurang disiplin, kurang bertanggung jawab, gaduh di kelas, kurang sopan kepada guru, membolos, kurang menunjukkan sikap Islami yang tertangkap basah oleh guru, misalnya: merokok, berkata kotor, tidak melakukan salat wajib, sering tidak ikut salat jamaah. Kebanyakan perilaku tersebut dipengaruhi oleh kakak kelas ataupun sudah menjadi kebiasaan di sekolah mereka sebelumnya (Latifah, 2019). Hal demikian begitu erat atas penumbuhan karakter siswa. Jika karakter yang demikian dibiarkan saja pada siswa, maka seterusnya siswa akan sulit melakukan perubahan, terlebih karakter yang tidak baik demikian mempengaruhi teman yang lain. Jika karakter yang sesuai norma demikian dibiarkan, maka fungsi pendidikan akan menjadi sia-sia.

Melihat fenomena demikian, maka penumbuhan karakter harus dilakukan secara teratur dan terarah agar siswa dapat mengembangkan dan mempraktikkan dalam kehidupan sehari-hari. Untuk mencapai tujuan tersebut, maka tidak lepas dari faktor-faktor penunjang yang tersedia dan terlaksana dengan baik, seperti guru dan staf yang berada di lingkungan sekolah. Peran guru sangatlah penting untuk menanamkan pendidikan karakter pada siswa. Pendidikan adalah bimbingan atau didikan secara sadar oleh pendidik terhadap perkembangan anak didik secara jasmani dan rohani untuk menuju terbentuknya kepribadian yang utama (Marimba, 2014). Guru sebagai suri tauladan bagi siswa-siswanya dalam menanamkan karakter yang baik sehingga dapat mencetak generasi yang baik. 
UU Nomor 20 Tahun 2003 tentang Sistem Pendidikan Nasional Bab 1 Pasal menyebut "Pendidikan adalah usaha sadar dan terencana untuk mewujudkan suasana belajar dan proses pembelajaran agar peserta didik secara aktif mengembangkan potensi dirinya untuk memiliki kekuatan spiritual keagamaan, pengendalian diri, kepribadian, kecerdasan, akhlak mulia serta ketrampilan yang diperlukan dirinya, masyarakat, bangsa dan negara" (Kemendikbud RI, 2003). Dalam Undang-undang demikian sudah jelas dikatakan bahwa pendidikan di Indonesia berfungsi mengembangakan kemampuan dan membentuk watak serta peradaban bangsa dan beberapa poinpoin yang telah disebutkan. Hal demikian sangat berkaitan dengan pembentukan karakter yang menjadikan peserta d.idik dapat mengembangkan potensi yang bermanfaat untuk diri sendiri dan orang lain sebagaimana pembentukan karakter lebih pada pembentukan watak peserta didik yang sesuai dengan budaya bangsa, sehingga karakter khas pada putra bangsa tetap terjaga.

Tujuan utama pendidikan agama Islam bukanlah pada pemahaman tentang agama namun pada keberagamaan peserta didik. Ini selaras dengan pergeseran epistemologi pendidikan Islam kontemprer, bahwasanya titik tekan keberagaman dan multikultural merupakan goals dari pendidikan Islam (Hanafi, n.d.). Dengan kata lain, yang diutamakan oleh pendidikan agama (Islam) bukan hanya knowing (mengetahui tentang ajaran dan nilai-nilai agama) ataupun doing (bisa memperaktikkan apa yang diketahui) setelah diajarkannya di sekolah, tetapi justru lebih mengutamakan being-nya (beragama atau menjalani hidup atas dasar ajaran dan nilai-nilai agama). Pendidikan agama harus lebih berorientasi pada tataran moral action, yakni agar peserta didik tidak berhenti pada tataran kompeten (competence), tetapi harus sampai memiliki kemauan (will), dan kebiasaan (habit) dalam mewujudkan ajaran dan nilai-nilai agama tersebut dalam kehidupan seharihari (Muhaimin, 2016).

Berbicara mengenai karakter di MA Al-Falah Karangrejo, mata pelajaran Pendidikan Agama Islam terutama sub Akidah Akhlak menjadi objek negatif atas perilaku siswa yang kurang terpuji (Nasrul, 2019). Perilaku kurang terpuji siswa MA Al-Falah Karangrejo ditandai dengan kurangnya rasa hormat kepada guru, terlambat masuk kelas, berkata kotor, dan sebagian siswa yang mengumpat di kelas saat pelaksanaan salat Zuhur berjamaah di masjid sekolah. Perilaku kurang terpuji siswa juga dibuktikan dengan suka berkata kasar, keras, dan jahil kepada teman, bahkan ada yang berkelahi. Dampak dari siswa yang berkelahi adalah guru Bimbingan dan Konseling memanggil orangtua dan siswa tersebut dan melakukan advokasi kepada mereka. Besarnya perilaku kurang terpuji demikian dilakukan setiap hari dan dengan subjek yang sama.

Namun sisi lain, mata pelajaran Akidah Akhlak lebih diminati siswa MA Al-Falah Karangrejo Pacitan karena berkaitan dengan norma, etika, dan perilaku sehari-hari yang menjadi kesatuan dalam diri siswa, sehingga siswa lebih antusias mengikuti KBM mata pelajaran tersebut. Dalam pembelajarannya, peran guru adalah kunci kesuksesan belajar. Guru menjadi agent of change atas perilaku dan karakter siswa disaat siswa mengampu mata pelajaran Akidah Akhlak. Peran guru begitu penting dalam menanamkan pendidikan karakter. Selama di sekolah, siswa lebih dekat dengan guru terutama saat kegiatan KBM berlangsung. Di sinilah guru dapat mengambil peran untuk menanamkan nilai-nilai karakter siswa. Lantas, bagaimana peran guru Akidah Akhlak dalam penanaman nilai-nilai karakter siswa di MA Al-Falah Karangrejo Pacitan?

Literatur terdahulu yang relevan dengan tema ini adalah penelitian yang dilakukan oleh (Sholihah \& Maulida, 2020) yang berjudul "Pendidikan Islam sebagai Pondasi Pendidikan Karakter". Peneliti menentukan fokus penelitian tentang pondasi pendidikan karakter berbasis 
pendidikan Islam. Parameter baik dan buruk karakter seorang memiliki standar tertentu menurut AlQur'an dan Hadis. Abdah menyebut Al-Qur'an dan Hadis sebagai dasar rujukan untuk mencari, membuat, dan mengembangkan paradigma, konsep, prinsip, teori, dan teknik pendidikan Islam, termasuk setiap upaya pendidikan.

Literatur selanjutnya ialah penelitian Mariana (2019) dengan judul "Inspirasi Kisah dalam Menstimulasi Character Building Anak Usia Dini”. Peneliti mengambil data film kartun Upin-Ipin sebagai data primer penelitian. Penelitian ini menggunakan teori stimulasi karakter Maria Montessori (1978). Fokus penelitian mengarah pada stimulus karakter anak. Peneliti menyebut nilai-nilai karakter dari stimulus anak dalam film kartun Upin-Ipin di antaranya adalah bertakwa, tanggung jawab, disiplin, gemar membaca, jujur, sopan, peduli, sikap yang baik, toleransi, kreatif, mandiri, rasa ingin tahu, semangat kebangsaan, menghargai, dan bersahabat.

Konsep pendidikan karakter juga ditulis oleh Wahidin (2017) dengan judul "Pendidikan Karakter bagi Remaja". Peneliti menentukan fokus penelitian pada proses pendidikan karakter pada remaja dan bukan anak-anak. Data penelitian didapat pada perilaku remaja secara studi pustaka. Hasil penelitian menyebutkan bahwa inovasi pola kemitraan peran orang tua di lingkungan keluarga dengan peran guru di lingkungan sekolah dalam pendidikan karakter bagi remaja dapat mengatasi berbagai masalah yang dihadapi saat ini dan masalah yang yang akan datang. Peneliti menjelaskan bahwa sinergisitas orangtua dan guru akan menjadi penentu keberhasilan pendidikan karakter. Orangtua sebagai madrasah pertama untuk penanaman karakter remaja, pengontrol sikap dan etika remaja, sedangkan guru sebagai penguat penanaman karakter yang disertai aspek kognitif.

Dari ketiga literatur terdahulu disebut bahwa pendidikan karakter dapat ditanamkan melalui media pendidikan Islam, film kartun, dan peran orangtua serta guru dalam mendidik anak. Subjek penelitian ketiga literatur mengarah pada anak, siswa, dan remaja. Untuk teori pendidikan karakter yang digunakan ketiga literatur di atas menyebut pendidikan karakter menurut Al-Qur'an dan Hadis, teori stimulus Maria Montessori (1978), dan konsep karakter menurut (Kemendikbud RI, 2011). Nilai signifikansi penelitian ini atas literatur terdahulu adalah peneliti menentukan fokus penelitian pada peran guru Akidah Akhlak dalam menanamkan nilai-nilai karakter siswa MA. AL-Falah Karangrejo Pacitan. Subjek penelitian adalah guru Akidah Akhlak MA Al-Falah Karangrejo, sedangkan data penelitian berupa perilaku dan peran guru tersebut.

\section{Guru dalam Orientasi Pendidian Karakter}

Guru adalah pendidik profesional dengan tugas utama mendidik, mengajar, membimbing, mengarahkan, melatih, menilai, dan mengevaluasi peserta didik pada pendidikan anak usia dini jalur pendidikan formal, pendidikan dasar, dan pendidikan menengah. Guru sebagai pendidik profesional mempunyai fungsi, peran, dan kedudukan yang sangat strategis. Guru sebagai tenaga profesional mempunyai visi terwujudnya penyelenggaraan pembelajaran sesuai dengan prinsipprinsip profesionalitas untuk memenuhi hak yang sama bagi setiap warga negara dalam memperoleh pendidikan yang bermutu (Kemendikbud RI, 2008). Peran guru dalam pendidikan karakter meliputi keteladanan, inspirator, motivator, dinamisator, dan evaluator (Asmani \& Makmur, 2011). 
Kelima peran guru sebagaimana dijelaskan oleh Asmani \& Makmur (2011) demikian secara komperhensif merupakan salah satu upaya menerapakan kompetensi pedagogik dan kompetensi profesional sebagaimana diamanatkan dalam Undang-Undang Republik Indonesia Nomor 14 Tahun 2005 Tentang Guru dan Dosen. Kompetensi Guru harus diupayakan dengan peran mengajar dalam kelas, berinteraksi dengan siswa, mendidik, dan menanamkan karakter. Ini adalah cara agar relasi guru dan siswa menjadi dekat sehingga misi pendidikan dapat tercapai yakni menanamkan nilainilai karakter.

Pusat Bahasa Departemen Pendidikan Nasional memberikan istilah "karakter" dengan sifatsifat bawaan, hati, jiwa, kepribadian, budi pekerti, perilaku, personalitas, sifat, tabiat, temperamen, watak. Adapun berkarakter adalah berkepribadian, berperilaku, bertabiat dan berwatak (Amri, 2011). Dalam bahasa Arab, karakter diartikan "khuluq wa sajiyyah wa țab' $\bar{u}$ ” (budi pekerti, tabiat atau watak). Karakter juga dapat diartikan "syakhsiyyah" yang berarti lebih dekat dengan personality (kepribadian) (Fitri, 2012). Hornby dan Parnwell mendefinisikan karakter sebagai kualitas mental atau moral, nama atau reputasi. Kemudian, Simon Philips menyebut karakter dengan kumpulan tata nilai yang menuju pada sistem yang melandasi pemikiran, sikap, dan perilaku yang ditampilkan. Doni Koesoema A, memberikan pendapat bahwa karakter sama arti dengan kepribadian. Kepribadian dianggap sebagai ciri atau karakteristik atau gaya atau sifat khas dari diri seseorang yang bersumber dari bentukan-bentukan yang diterima dari lingkungan (Kemendikbud RI, 2011).

Konsep pendidikan karakter tidak hanya berhenti dari sisi terminologi, melainkan ada dua pendekatan untuk melihat sisi ini. Pertama memandang pendidikan karakter dalam cakupan pemahaman moral yang sifatnya lebih sempit (narrow scope to moral education). Kemudian kedua melihat pendidikan karakter dari sudut pandang pemahaman isu-isu moral yang lebih luas, terutama melihat keseluruhan dalam peristiwa pendidikan itu sendiri (educational happenings) (Koesoma, 2010). Kedua pendekatan sebenarnya dualisme yang memiliki padanan yakni karakter. Karakter akan melekat dengan pembentukan moral dan upaya moral itu berkembang atas sifat manusia. Dua pendekatan ini terintegrasi dengan nilai jiwa peserta didik/siswa.

Nilai-nilai karakter dapat diimplementasikan dalam kurikulum sekolah. Kurikulum dalam konteks pendidikan karakter terdapat dalam berbagai kegiatan dan pengalaman peserta didik yang dilakukan di dalam dan di luar kelas dengan pengawasan pihak sekolah (Masduqi, 2020).

\section{Metode Penelitian}

Jenis penelitian yang dilakukan di MA Al-Falah Karangrejo Pacitan ini menggunakan penelitian lapangan yang bersifat kualitatif-deskriptif dan didasarkan pada pengamatan objektif partisipatif terhadap peran guru Akidah Akhlak dalam menanamkan karakter siswa MA Al-Falah Karangrejo Pacitan. Fenomena yang diteliti dilalui dengan proses pembelajaran mata pelajaran Akidah Akhlak, peran guru Akidah Akhlak, lingkungan sekolah, perilaku siswa, dan segala aktivitas yang ada di sekolah. Subjek penelitian ini adalah guru pengampu mata pelajaran Akidah Akhlak, kepala madrasah, dan siswa. Adapun lokasi penelitian yang dijadikan objek penelitian adalah MA Al-Falah Karangrejo Pacitan.

Penelitian ini dilakukan selama lima bulan dimulai pada bulan Maret_Agustus 2019 dengan lokasi penelitian di MA Al-Falah Karangrejo Pacitan. Dari lima bulan tersebut, dua bulan peneliti 
gunakan untuk penggalian data dan informasi di lokasi penelitian. Kehadiran peneliti di lokasi penelitian dilakukan secara berkala, yakni di saat KBM mata pelajaran Akidah Akhlak untuk penggalian data internal terkait peran guru dalam menanamkan karakter siswa dan peneliti melakukan observasi perilaku siswa MA Al-Falah Karangrejo Pacitan serta melakukan wawancara kepada pihak yang terkait untuk penggalian data eksternal. Kemudian tiga bulan berikutnya peneliti gunakan untuk penulisan hasil laporan penelitian dan seminar hasil penelitian.

Data primer dalam penelitian ini adalah segala bentuk aktivitas guru matapelajaran Akidah Akhlak dalam menanamkan nilai-nilai karakter siswa, sedangkan data sekunder berupa segala aktivitas guru di luar kegiatan pembelajaran. Data sekunder juga digali melalui dokumentasidokumentasi kegiatan belajar mengajar mata pelajaran Akidah Akhlak dan perilaku siswa.

Teknik pengumpulan data menggunakan wawancara, observasi, dan dokumentasi. Wawancara yang digunakan peneliti bersifat bebas, inguided interview, yakni pewawancara bebas menanyakan apa saja, tetapi juga mengingat data-data yang akan dikumpulkan (Kunandar, 2012). Peneliti melakukan wawancara kepada guru Akidah Akhlak terkait upaya yang dilakukan guna menanamkan nilai-nilai karakter keapada siswa, perilaku dan perkembangan siswa dan segala aktivitas yang ada dalam pembelajaran Akidah Akhlak di MA Al-Falah Karangrejo. Instrumen yang peneliti gunakan adalah pedoman lembar wawancara yang tidak terlalu mengikat. Teknik observasi dijalani dengan mengamati dan mencatat letak geografis MA Al-Falah Karangrejo Pacitan, kondisi siswa, struktur organisasi, kegiatan yang dilakukan guru dalam penanaman pendidikan karakter, serta observan meneliti langsung masuk dalam kelas meneliti proses KBM di MA Al-Falah Karangrejo. Teknik ini didefinisikan sebagai pengamatan dan pencatatan fenomena-fenomena yang diselidiki (Hadi, 2013). Kemudian teknik dokumentasi. Peneliti mengumpulkan dokumen-dokumen yang membantu dalam mengumpulkan data penelitian. Dokumen yang didokumentasikan memiliki relevansi dengan penelitian sepeti Rencana Pelaksanaan Pembelajaran (RPP), buku-buku yang mendukung pendidikan karakter, dan foto proses pembelajaran mata pelajaran Akidah Akhlak di MA Al-Falah Karangrejo Pacitan.

Peneliti melakukan analisis data dengan menggunakan model Miles dan Huberman yakni mengumpulkan data, mereduksi data, penyajian data, dan penarikan kesimpulan (Sugiyono, 2006). Langkah konkrit pada tahap ini bermula dengan peneliti mengamati fenomena-fenomena yang tampak dalam kegiatan proses KBM mata pelajaran Akidah Akhlak seperti cara belajar, perilaku guru pada siswa, dan respon siswa atas yang dilakukan guru. Fenomena demikian direduksi dan disajikan secara sistemartis berdasarkan jenis dan kelompok data. Langkah selanjutnya adalah menarik kesimpulan. Pada tahap ini peneliti melakukan interpretasi data sebagai hasil dan pembahasan penelitian.

Untuk keabsahan data peneliti menggunakan teknik Triangulasi yaitu membandingkan atau mengecek balik dengan sesuatu yang berbeda. Dengan melakukan kroscek dan banding atas hasil observasi yang dilakukan di MA Al-Falah Karangrejo Pacitan dengan hasil wawancara kepada guru Akidah Akhlak, kepala madrasah, dan siswa MA Al-Falah Karangrejo. Tahap lebih lanjut validasi data peneliti juga membandingkan hasil dokumentasi atas foto proses pembelajaran Akidah Akhlak dengan hasil wawancara dan observasi di MA Al-Falah Karangrejo. 


\section{Hasil}

\section{Strategi Guru dalam Menanamkan Karakter Siswa}

Data observasi dan wawancara menegaskan bahwa guru Akidah Akhlak di MA Al-Falah Karangrejo memiliki strategi-strategi guna menanamkan nilai-nilai karakter siswa semisal guru berpakaian yang sopan guna menanamkan etika berpakaian dan berseragam sekolah kepada siswa untuk selalu memakai seragam dan atribut madrasah secara lengkap. Guru memberi contoh etika siswa yang memiliki akhlak mulia, agar siswa dapat menaati peraturan dengan baik. Guru memberi sangsi bagi siswa yang terbukti melakukan pelanggaran, semisal siswa yang tidak mengikuti salat Duha, maka siswa diberi sanksi dengan melakukan salat Duha sendiri di kantor guru dan disaksikan oleh semua guru.

Strategi lain yang diterapkan kepada siswa agar memiliki karakter dan kebiasaan yang baik adalah dengan menganjurkan siswa datang ke sekolah tepat waktu. Hal ini merupakan pendidikan karakter kepada siswa sebelum pelajaran dimulai, agar siswa terbiasa disiplin dan menghargai waktu. Menaati peraturan madrasah dan perintah guru. Budaya siswa untuk menaati peraturan sekolah dapat dibuktikan dengan minimnya jumlah pelanggaran yang dilakukan siswa MA Al-Falah Karangrejo.

Strategi guru berikutnya adalah mewajibkan siswa untuk menjaga kebersihan madrasah dengan cara tidak membuang sampah sembarangan, karena sudah disediakan tempat sampah. Membuang sampah pada tempatnya dilakukan agar tidak membuat keadaan kelas berantakan baik dari susunan bangku dan sarana-prasarana kelas. Kebiasaan membuang sampah pada tempatnya sejatinya adalah perilaku sepele, namun pada hal ini sering dilalaikan orang. Banyak orang cenderung lalai melakukan hal kecil ini, seolah membuang sampah pada tempatnya adalah hanya edukasi untuk anak kecil bukan diperuntukkan bagi orang dewasa. Orang-orang yang lalai membuang sampah pada tempatnya tidak menyadari betapa membuang sampah pada tempatnya dapat mencegah penyakit dan meningkatkan estetika.

Guru menanamkan kebiasaan ramah terhadap orang lain dengan cara menganjurkan selalu menyapa ketika bertemu dengan teman madrasah. Dengan menyapa, murah senyum, dan bertanya kabar, maka akan menimbulkan rasa empati dan menghargai orang lain. Contoh ini agar dapat diterapkan siswa untuk selalu menyapa teman disaat bertemu dan berdampingan. Saling menyapa adalah kebiasaan masyarakat Timur terlebih masyarakat Indonesia. Saling menyapa dapat menjadi pintu pertama mengekspresikan etika-etika baik dalam kehidupan.

Untuk melatih kedisiplinan, siswa dilarang membawa handphone dan barang-barang berharga. Sekolah adalah proses edukasi untuk membiasakan hidup sederhana. Guru memberi contoh kepada siswa agar senantiasa hidup sederhana di lingkungan sekolah maupun masyarakat. Jikapun membawa handphone maka hanya sebatas untuk keperluan komunikasi. Siswa tidak diperkenankan mengakses game online yang ada dalam aplikasi handphone. Penggunaan handphone siswa tetap dalam monitoring guru.

Dari strategi dan contoh di atas dapat disimpulkan bahwa peran guru Akidah Akhlak sangat memengaruhi dalam menanamkan karakter siswa MA Al-Falah Karangrejo Pacitan, meskipun pada kenyataanya masih ada beberapa siswa yang belum melakukan yang dicontohkan guru. 


\section{Faktor Pendukung dan Penghambat}

Dalam lingkungan pendidikan tentu tidak lepas dari faktor pendukung dan penghambat atas misi pendidikan yang direncanakan. Dengan adanya faktor pendukung sebaiknya tidak menjadikan pelaku pendidikan selalu optimis dan mendiskreditkan perilaku yang lain.

Data-data hasil observasi dan wawancara pada guru Akidah Akhlak MA Al-Falah Karangrejo Pacitan menunjukkan adanya faktor yang mendukung dan menghambat peran guru dalam menanamkan nilai-nilai karakter kepada siswa. Di antara faktor penghambat dan pendukung sebagaimana dijelaskan pada deskripsi berikut

Faktor Pendukung. Dari penelitian dilakukan peneliti mendapati faktor pendukung atas peran guru dalam menanamkan nilai-nilai karakter kepada siswa, yakni terciptanya budaya saling menyapa di lingkungan MA Al-Falah Karangrejo Pacitan. Budaya saling menyapa selalu dilakukan masyarakat sekolah baik dari guru kepada siswa, guru kepada orangtua, maupun kepala madrasah kepada guru atau karyawan di setiap waktu dan kesempatan. Selain itu terciptanya pendekatan humanistik, artinya di saat guru menemukan permasalahan terkait dengan penanaman nilai-nilai karakter siswa, maka yang pertama kali dilakukan adalah dengan mendengarkan alasan siswa melakukan hal demikian (tabāyun). Pendekatan humanistik juga dilakukan kepala madrasah kepada guru di saat guru terlambat datang ke madrasah.

Faktor Penghambat. Walaupun faktor pendukung berasal dari lingkungan keluarga, tetapi tidak semua keadaan keluarga siswa bersifat homogen, sehingga keluarga menjadi salah satu faktor penghambat terwujudnya misi pendidikan. Contoh dari faktor ini adalah kurangnya antusias orangtua kepada siswa, sehingga perilaku dan kebiasaan siswa yang dilakukan dalam keluarga tidak sesuai dengan yang dilakukan saat di madrasah, semisal pembiasaan berpakaian yang sopan. Hasil wawancara kepada salah satu siswa menjelaskan bahwa terkadang dijumpai orangtua yang belum mengenakan pakaian yang sopan. Selain itu juga mengarah pada pembiasaan salat siswa, madrasah tidak bisa menjamin kejujuran siswa untuk mengerjakan salat lima waktu di rumah. Tidak adanya relevansi perilaku di madarasah dan keluarga menjadi kendala madrasah dalam menanamkan nilainilai karakter kepada siswa. Faktor penghambat yang lain berasal dari madrasah itu sendiri, baik dari guru, karyawan, dan siswa.

\section{Pembahasan}

Sebagaimana dijelaskan sebelumnya bahwa guru sebagai pendidik profesional mempunyai fungsi, peran, dan kedudukan yang sangat strategis. Guru sebagai tenaga profesional mempunyai visi terwujudnya penyelenggaraan pembelajaran sesuai dengan prinsip-prinsip profesionalitas untuk memenuhi hak yang sama bagi setiap warga negara dalam memperoleh pendidikan yang bermutu (Kemendikbud RI, 2008). Peran guru dalam pendidikan karakter meliputi keteladanan, inspirator, motivator, dinamisator, dan evaluator (Asmani \& Makmur, 2011).

Jika mengutip pendapat di atas, guru Akidah Akhlak di MA Al-Falah Karangrejo Pacitan kini tengah berupaya menjalani perannya sebagai teladan bagi siswa-siswi di madrasah tersebut. Guru Akidah Akhlak tengah mengaktualisasikan semaksimal mungkin untuk memberi teladan dalam bentuk perilaku disiplin dan menghargai waktu belajar. Keteladanan guru memiliki nilai signifikansi yang penting daripada ucapannya. Teladan disiplin yang diajarkan guru saat memasuki 
sekolah dan menaati peraturan sekolah merupakan perihal kecil tetapi sarat dengan arti. Ada makna relatif dalam pemberian keteladanan guru kepada siswa di MA Al-Falah Karangrejo Pacitan, bahwa keteladanan guru menjadi tolak ukur perkembangan karakter siswa. Siswa akan lebih mudah mengambil sikap dan perilaku yang dilakukan oleh guru saat di sekolah daripada menanggapi perintah dan ucapan guru. Maka dari itu, dalam teologi Islam disebutkan bahwa "tindakan akan lebih mengena daripada ucapan".

Peran guru Akidah Akhlak di MA Al-Falah Karangrejo Pacitan sebagai sosok dinamisator adalah guru mampu menmberikan advokasi kepada siswa untuk selalu menjaga kebersihan di kelas seperti membuang sampah pada tempatnya dan tidak mengotori kelas. Guru Akidah Akhlak demikian telah memberikan pemahaman arti penting menjaga kebersihan dan kesehatan hidup, sehingga siswa MA Al-Falah Karangmojo terbiasa untuk membuang sampah pada tempatnya, tidak mengotori lingkungan madrasah, tidak mencoret-coret bangku, kursi, dan tembok kelas sebagai bentuk pemeliharaan kebersihan dan estetika madrasah. Perihal ini sangat penting untuk dilakukan siswa di madrasah sebagai bentuk tanggung jawab mengelola madrasah, sehingga dapat diaktualisasikan di rumah dan masyarakat. Sosok guru Akidah Akhlak sebagai seorang dinamisator dapat dicontohkan dengan penggerak salat Duhur berjamaah di madrasah. Seluruh siswa MA AlFalah diwajibkan mengikuti salat berjamaah di masjid di saat ISHOMA. Hal ini sebagai bentuk pelatihan kepada siswa agar senantiasa melaksanakan tanggungjawabnya kepada Tuhannya.

Lebih lanjut pada peran guru Akidah Akhlak MA Al-Falah Karangrejo Pacitan sebagai evaluator. Hal ini dapat dicontohkan saaat guru Akidah Akhlak melakukan evaluasi di sekolah dan luar sekolah. Di sekolah misalnya guru melakukam kontrol terhadap siswa-siswi yang tidak mengikuti salah Duhur berjamaah di masjid madrasah. Kemudian, dari siswa-siswa yang tidak mengikuti salat Duhur berjamaah tersebut dipanggil guru dan diberi sangsi. Sangsi yang diberikan guru bersifat edukasi, yakni siswa disuruh membersihkan ruangan yang kotor di lingkungan madrasah. Dengan demikian, harapannya siswa dapat menjadi jera disaat tidak mengikuti kegiatan salat Duhur berjamaah di masjid. Kemudian bentuk evaluasi di luar sekolah adalah guru Akidah Akhlak Karangrejo Pacitan sangat aktif untuk melakukan home visite dan komunikasi dengan wali murid. Hal ini sebagai bentuk adanya hubungan edukasi yang vertikal antara guru dan wali murid. Di saat itu pula guru aktif bertanya tentang perkembangan salat lima waktu di rumah. Harapannya adalah agar orang tua juga ikuti berpartisipasi mengontrol kegiatan salat lima waktu siswa saat di rumah sebagai perwujudan nilai-nilai disiplin dan tanggung jawab kepada agama dilakukan oleh siswa MA Al-Falah Karangrejo Pacitan. Masih dalam bidang evaluasi, guru tersebut juga mengontrol siswa-siswi yang mengenakan perhiasan dan membawa handphone di madrasah. Hal ini sangat penting dilakukan oleh guru guna menjaga etika yang harus dilakukan siswa di madrasah. Jika siswa diperbolehkan membawa handphone semaunya, maka akan berdampak pada kurang kondusifnya kegiatan belajar mengajar. Begitu juga jika siswa-siswi bebas mengenakan perhiasan, maka sangat rawan akan terjadi tindak kriminalitas.

Peran guru demikian sebagaimana yang dicontohkan di atas dapat dijadikan sebagai inspirasi siswa. Guru Akidah Akhlak MA Al-Falah Karangrejo Pacitan telah memberi inspirasi akademik dan perilaku kepada siswa. Peran guru Akidah Akhlak di sini menjadi sebuah keharusan, dimana ia terbebani dengan materi belajar akhlak yang diajarkan kepada siswa. Dengan demikian, menjadi sosok panutan dan inspirasi bagi siswa adalah suatu kewajiban terutama dalam bidang etika dan akhlak. Bentuk perilaku yang dapat dijadikan inspirasi kepada siswa adalah sikap disiplin dan 
menghargai waktu. Guru tersebut telah memberikan contoh disiplin dan menghargai waktu di madrasah. Dalam bidang etika, guru Akidah Akhlak telah memberikan contoh untuk saling menyapa kepada setiap orang yang dilaluinya. Dalam bidang evaluasi, guru Akidah Akhlak telah memberikan sangsi kepada siswa yang tidak tertib dan aktif berkomunikasi kepada orangtua siswa atas perkembangan-perkembangan siswa di rumah, sehingga upaya-upaya guru demikian dapat dijadikan inspirasi siswa untuk bertindak dan berperilaku ke depan.

Dengan demikian, peran guru sebagaimana diungkap Asmani \& Makmur (2011) telah dilakukan oleh guru Akidah Akhlak MA Al-Falah Karangrejo Pacitan. Peran guru tersebut sangat berarti dalam penanaman nilai-nilai pendidikan karakter siswa dan masyarakat madrasah. Disaat pendidikan karakter menjadi perhatian yang penting di madrasah, maka madrasah akan menjadi lembaga alternatif masyarakat.

\section{Kesimpulan}

Peran guru Akidah Akhlak dalam menanamkan nilai-nilai karakter siswa MA Al-Falah Karangrejo Pacitan memberi pengaruh besar kepada siswa. Perihal ini dbuktikan dengan guru memberi contoh etika-etika yang baik saat di lingkuangan madrasah. Strategi yang dilakukan guru diantaranya dengan manganjurkan siswa datang ke madrasah tepat waktu, menaati peraturan madrasah dan perintah guru. Guru mewajibkan siswa untuk menjaga kebersihan madrasah dengan cara tidak membuang sampah sembarangan, tidak membawa tepelon seluler dan barang-barang berharga, tidak membuat keadaan kelas berantakan, saling menyapa, dan memberi sanksi siswa yang melanggar peraturan madrasah.

Didapati faktor pendukung dalam menanamkan nilai-nilai karakter siswa di MA Al-Falah Karangrejo Pacitan yakni terciptanya budaya saling menyapa di lingkungan madrasah, melakukan tabāyun atas pelanggaran yang dilakukan siswa, dan melakukan pendekatan humanistik kepada masyarakat sekolah. Kemudian faktor yang menghambat penanaman nilai-nilai karakter siswa di madrasah tersebut adalah adanya orangtua yang belum mengenakan pakaian sopan, kurang jujurnya siswa dalam melakukan salat lima waktu di rumah, kurang relevansinya perilaku siswa yang dilakukan di madrasah dan keluarga. Faktor lain yang menghambat adalah tidak adanya relevansi perilaku di madarasah dan keluarga. Kemudian faktor madrasah itu sendiri, baik dari guru, karyawan, dan siswa.

\section{Pernyataan}

Terima kasih peneliti haturkan kepada stakeholder MA Al-Falah Karangrejo Pacitan yang telah menyediakan objek penelitian sehingga penelitian ini selesai dilaksanakan sebagai bentuk pengejawantahan Tri Darma Perguruan Tinggi dalam bidang penelitian bagi peneliti. Adanya penelitian ini diharapkan memiliki kontribusi secara akademis dan pragmatis di lokasi penelitian guna memgembangkan potensi madrasah agar menjadi madrasah unggulan di bidang pendidikan karakter di wilayah kabupaten Pacitan. 


\section{Referensi}

Amri, S. (2011). Implementasi Pendidikan Karakter Dalam Pembelajaran. Jakarta: Prestasi Pustaka. Asmani \& J. Makmur. (2011). Buku Panduan Internalisasi Pendidikan Karakter di Sekolah. Yogyakarta: DIVA Press.

Budiwan, J. et al (2020). Validity Test of the Family Supported Collaborative Learning (FSCL) Model to Instill Character Values to Junior High School Students. Universal Journal of Educational Research, 8 (3D), 1 - 6. DOI: 10.13189/ujer.2020.081701.

Fitri, A. (2012). Pendidikan Karakter berbasis Nilai \& Etika di Sekolah. Yogyakarta: Arruz Media.

Hadi, S. (2013). Metode Research. Malang: Andi Offset.

Hanafi, W. (n.d.). PERGESERAN EPISTEMOLOGI PENDIDIKAN ISLAM.

Koesoma, D. (2010). Pendidikan Karakter: Strategi Mendidik Anak di Zaman Global. Jakarta: Grasindo.

Kunandar. (2012). Langkah Mudah Penelitian Tindakan Kelas Sebagai Pengembangan Profesi Guru. Depok: Raja Grafindo Persada.

Latifah, Z. (2019). Karakter Siswa MA Al-Falah Karangrejo Pacitan (No. 1).

Lubis, M. (2009). Evaluasi Pendidikan Nilai. Yogyakarta: Pustaka Pelajar.

Mariana, M. (2019). Inspirasi Kisah Dalam Menstimulasi Character Building Anak Usia Dini. SCAFFOLDING: Jurnal Pendidikan Islam Dan Multikulturalisme, 1(01), 58-66.

Marimba, A. (2014). Pengantar Filsafat Pendidikan Islam. Bandung: Remaja Rosdakarya.

Masduqi, M. (2020). MENUMBUHKAN KARAKTER PEDULI SOSIAL MELALUI KEGIATAN EKSTRA-KURIKULER. MIYAH: Jurnal Studi Islam, 16(1), 94-117. https://doi.org/http://dx.doi.org/10.33754/miyah.v16i1.245.g188

Muhaimin. (2016). Nuansa Baru Pendidikan Islam: Mengurangi Benang Kusut Dunia Pendidikan. Depok: Raja Grafindo Persada.

Nasrul. (2019). Karakter Siswa MA Al-Falah Karangrejo Pacitan (No. 2).

Kemendikbud RI. (2003). Sistem Pendidikan Nasional.

Kemendikbud RI. (2008). Peraturan Pemerintah No.74 Tahun 2008 Tentang Guru Pasal 1 ayat (1).

Kemendikbud RI. (2011). Modul Materi Pendidikan Karakter Bangsa (p. 245).

Sholihah, A. M., \& Maulida, W. Z. (2020). Pendidikan Islam sebagai Fondasi Pendidikan Karakter. QALAMUNA: Jurnal Pendidikan, Sosial, Dan Agama, 12(1), 49-58.

Sugiyono. (2006). Metode Penelitian Pendidikan. Bandung: Alfabeta.

Wahidin, U. (2017). Pendidikan Karakter Bagi Remaja. Edukasi Islami: Jurnal Pendidikan Islam, $2(03)$.

Zubaidi. (2011). Desain Pendidikan Karakter. Jakarta: Prenada Media Group. 